\title{
Cotidianidad y proyecto político. Una perspectiva de estudio de la modernidad en la dictadura uruguaya. 1973-1984
}

\section{Vida cotidiana e projeto político. Uma perspectiva de estudo da modernidade na ditadura uruguaia. 1973-1984}

\section{Everyday life and political project. One perspective off study about modernity in Uruguayan dictatorship. 1973-1984}

Gerardo Albistur $^{1}$

\begin{abstract}
Resumen
El artículo fundamenta la pertinencia de un estudio de las dictaduras latinoamericanas de fines del siglo XX, desde una perspectiva que observe los fenómenos de la época como consustanciales a las sociedades donde se produjeron. A través del caso uruguayo de la dictadura cívico-militar (1973-1984), se propone un estudio desde la cotidianidad en dictadura y su relación con el proyecto político e institucional del régimen. Para este fin, se establece un marco teórico que concibe a las dictaduras como períodos agudos de la modernidad en la región, y se demuestra cómo una perspectiva comunicacional puede contribuir con este objetivo.
\end{abstract}

Palabras-clave: dictadura; proyecto político; comunicación

\section{Resumo}

O artigo demonstra a relevância de um estudo das ditaduras latino-americanas no final do século $\mathrm{XX}$, a partir de uma perspectiva que observa os fenômenos do período como produto das sociedades em que foram produzidos. Com base no caso uruguaio da ditadura civil-militar (1973-1984), propõe-se um estudo a partir do cotidiano durante a ditadura e sua relação com o projeto político e institucional do regime. Para tal fim, foi estabelecido um quadro teórico que concebe as ditaduras como períodos agudos da modernidade na região e se demonstra como uma perspectiva da comunicação pode contribuir para esse objetivo.

Palavras-chave: ditadura; projeto político; comunicação

Artigo recebido em: 9 de janeiro de 2015

Artigo aprovado para publicação em: 7 de abril de 2015

\footnotetext{
${ }^{1}$ Professor de la Facultad de Información y Comunicación. Universidad de la República de Uruguai. Email: albistur@vera.com.uy.

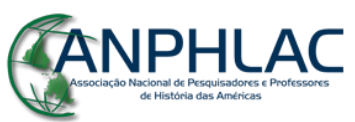

Revista Eletrônica da ANPHLAC, ISSN 1679-1061, №. 18, p. 162-188, jan./jul. 2015. http://revista.anphlac.org.br/
} 
Cuando promedian tres décadas del retorno a la democracia en los países del Cono Sur latinoamericano, la investigación sobre las dictaduras que se desataron en la región en la segunda mitad del siglo XX se ha desarrollado en dos vertientes que, si bien es posible diferenciarlas, se combinan y asisten mutuamente. Por un lado, con distintos niveles de avance en cada país de la región, la investigación sobre la verdad ha perseguido el objetivo de sustentar las políticas de memoria y derechos humanos y el juicio a los responsables de delitos de lesa humanidad; por otro, la investigación académica ha intentado encontrar regularidades desde una multiplicidad de aproximaciones disciplinares sin que sea posible asegurar si la diversidad implica proliferación o simplemente dispersión teórica.

A 41 años de la disolución del Parlamento el 27 de junio de 1973 y el inicio de la dictadura cívico - militar (1973-1984) en Uruguay, la investigación académica nacional ha hecho su contribución al conocimiento sobre este período de la historia reciente en el continente latinoamericano. En particular, la producción uruguaya al respecto ha transitado por la complejidad del período y ha sido fértil en cuanto a miradas disciplinares, perspectivas teóricas y grados de especificidad y generalización. En el artículo Pensar el pasado reciente: antecedentes y perspectivas publicado diez años atrás (MARCHESI, MARKARIAN, RICO, YAFFÉ, 2004, p. 5-12), que cuenta con una posterior actualización (MARKARIAN, MARCHESI, 2012, p. 213-242), varios autores han realizado un intento por ordenarla, que al mismo tiempo es la verificación de un estado del arte difícil de clasificar. Este esfuerzo agrupa por un lado los enfoques "estructurales" desde la historia, la economía o el campo cultural y social, por otro los que se presentan como específicamente politológicos cuando se detienen, sobre todo, en el análisis del formato del sistema político tanto en la etapa que precedió al golpe de Estado como en la fase de transición a la democracia, y finalmente los que destacan una perspectiva con énfasis en la subjetividad de los individuos y los grupos, fundamentalmente en lo relativo a las consecuencias individuales y sociales de la represión estatal y la violencia política. Aun con esta acumulación verificada, los investigadores que se han ocupado de esta tarea -además de contribuir en algunas de las perspectivas que detectan- señalan las insuficiencias y los límites del conocimiento

\section{CANPHLAC}

Revista Eletrônica da ANPHLAC, ISSN 1679-1061, №. 18, p. 162-188, jan./jul. 2015. http://revista.anphlac.org.br/ 
disponible sobre la dictadura y reclaman, entre otros aspectos, tanto la ampliación del período investigado como la necesidad avanzar en la definición teórica del tipo de régimen que significó la dictadura cívico - militar. Por lo demás, existe una profusa literatura testimonial y periodística sumamente variada en cuanto a géneros, puntos de vista y propósitos.

Buena parte de esta bibliografía se asienta en un debate a la vez político y social que intenta responder a la interrogante que emerge una vez que la descripción del período ha sido abundantemente tratada: por qué ocurrió la represión política, qué es lo que explica los costados más dramáticos del terror, los desaparecidos, los detenidos arrojados al mar desde los "aviones de la patria” (CASULLO, 1996, p. 191), el secuestro de niños, las torturas, la prisión, los asesinatos y enterramientos clandestinos, el exilio de miles de personas. En pocas palabras, cuál es la explicación política, histórica, cultural, que permita entender por qué ocurrió, respuesta a la que no parece accederse únicamente con la descripción de la forma en que la represión se produjo.

La necesidad de denunciar lo ocurrido, y luego de sostener la memoria como fundamento para la no repetición, subrayó el dramatismo de la época, lo que sin duda fue determinante para extender la condena y consolidar los procesos de redemocratización. Varios han sido los objetos de esta reivindicación: además del testimonio, el emplazamiento en las ciudades del Cono Sur latinoamericano de sitios y "marcas" de la memoria, de museos destinados a mantener la mirada en lo ocurrido e investigaciones impulsadas por los estados para determinar el destino de los desaparecidos. Como resultado de procesos que ocurrieron de manera diversa en la región, los Estados favorecieron la creación organismos específicamente destinados a recopilar información sobre las violaciones a los derechos humanos durante las dictaduras. Estas “«comisiones de la verdad» se constituyeron en la región en el principal modo de producir un saber y una verdad sobre estos procesos y [...] el Nunca Más argentino fue un modelo insoslayable par todas ellas" (CRENZEL, 2008, p. 18). A la Comisión Nacional sobre la Desaparición de Personas (CONADEP) creada en Argentina en 1983, siguieron la Comisión Nacional de Verdad y Reconciliación de Chile en 1990, la Comisión Para la Paz de Uruguay en 2000, y más recientemente la

\section{GANPHLAC}

Revista Eletrônica da ANPHLAC, ISSN 1679-1061, №. 18, p. 162-188, jan./jul. 2015. http://revista.anphlac.org.br/ 
Comissão Nacional da Verdade en Brasil, creada en 2012. Estas investigaciones promovidas por el Estado, fueron a menudo precedidas por investigaciones realizadas por organizaciones vinculadas a la defensa de los Derechos Humanos. ${ }^{2}$ Para Stampa, Santana y Rodrigues (2014, p. 47), las comisiones de la verdad tienen por objetivo conocer los hechos y preservar la memoria social sobre los mismos como garantía para las democracias actuales: "[...] que os fatos relacionados a essas violações não sejam esquecidos para que não se repitam $[\ldots]$ ”.

No obstante, junto al avance de la investigación sobre lo ocurrido, interrogantes del tipo “¿cómo fue posible que ocurriese tal colapso en Argentina y Uruguay [...]?” (GATTI, 2008, p. 41), o “[...] por qué el llamado Estado de compromiso devino un Estado criminal a través de la tortura masiva y el asesinato político [...]” (RICO, 2005, p. 30), corresponden a un orden distinto respecto a las interrogantes que formula la búsqueda de la verdad sobre detenciones, asesinatos o desapariciones. Mientras continúa la investigación que responde a la demanda de verdad sobre lo ocurrido, los autores advierten la insuficiencia en el porqué, en las razones para lo que se expresa como sinrazón, los motivos de aquello que aparece como injustificable, las fuentes y los asientos, en una palabra, la lógica. Esta derivación ocurre cuando el dato sobre la represión estatal durante las dictaduras se presenta sin dificultades como el relato de lo irracional, y sin embargo, lo irracional y el absurdo parecen categorías insuficientes para explicar más de una década de terrorismo de Estado. En consecuencia, la investigación que intenta preservar la memoria obliga a explorar con énfasis el porqué, relevo de cualquier interpretación que observe al período como un "paréntesis" ahistórico, sin origen y sin continuidad, explicable solo como anomalía en lo sucesivo evitable a través de la exposición del horror.

En la bibliografía de referencia, si bien muestran escasa continuidad, es posible encontrar perspectivas como la propuesta. Especialmente el libro de Gabriel Gatti El detenido desaparecido (2008) representa una aportación significativa que Markarian y

\footnotetext{
${ }^{2}$ Ejemplos de estas aportaciones son el informe Brasil Nunca Mais que comenzó a elaborarse en 1979 a partir de investigaciones realizadas por el Consejo Mundial de Iglesias, la Arquidiócesis de São Paulo y la Iglesia Presbiterana, o el informe Uruguay Nunca Más, que realizó el Servicio Paz y Justicia (Serpaj) en 1989.
}

\section{GANPHLAC}

Revista Eletrônica da ANPHLAC, ISSN 1679-1061, №. 18, p. 162-188, jan./jul. 2015. http://revista.anphlac.org.br/ 
Marchesi (2012, p. 233) vinculan con la reconstrucción de la memoria, cuando el autor observa a la desaparición forzada como un aspecto del

[...] proceso civilizatorio, esto es, una retórica sobre la construcción de la vida social en la que a partes iguales trabajan el discurso de la creación ex nihilo de esta sociedad junto con el de la eliminación de lo que sobre en ella, en la que pesa tanto la construcción de lo que se ajusta al proyecto como la desaparición y/o domesticación de lo disfuncional, de lo incómodo, de lo conflictivo (GATTI, 2008, p. 39).

Gatti observa, en el análisis de los casos uruguayo y argentino, una suerte de continuidad de las dictaduras respecto al proyecto civilizatorio que caracterizó a estas sociedades: la exacerbación de una racionalidad que combina construcción (política, social, moral, económica), con eliminación de aquellos componentes (individuos, organizaciones, ideologías) incompatibles con el proyecto previsto. Su hipótesis sobre la desaparición forzada es sugestiva: "la desaparición forzada de personas no es barbarie sino que, al contrario, es modernidad exacerbada" (GATTI, 2008, p. 42). De esta manera la hipótesis permite reconocer un episodio excepcional (la desaparición de personas), explicable no como acontecimiento anacrónico (la barbarie) sino como proceso esencialmente moderno, racional, en palabras de Nicolás Casullo (2003, p. 19) refiriéndose a la modernidad "[...] un proceso esperanzador [que] le otorga a la historia un sentido, un fin, una meta [...]".

Las dictaduras en este caso se observan desde un enfoque en donde la ruptura, lo excepcional, está en la exacerbación de lo corriente, esto es, del mismo proyecto modernizador de las sociedades, cotidianamente implicado en todas las relaciones sociales y políticas, en la cultura, esta vez con el objetivo de superar el intento fallido anterior y alcanzar esa meta propiamente moderna del desarrollo.

Con este antecedente, en el presente artículo se fundamentará la pertinencia del estudio de las dictaduras desde una perspectiva que observe los fenómenos de la época como consustanciales a las sociedades donde se produjeron. Tomando como caso la dictadura uruguaya, tal condición de indivisibilidad permite la observación desde una

\section{GANPHLAC}

Revista Eletrônica da ANPHLAC, ISSN 1679-1061, №. 18, p. 162-188, jan./jul. 2015. http://revista.anphlac.org.br/ 
doble perspectiva: i) la cotidianidad en dictadura, en relación con ii) el proyecto político e institucional del régimen. Dos universos en apariencia inconexos y no obstante mutuamente subordinados, puesto que el proyecto solo se tornaría realmente viable en la medida que fuera aceptado y adoptado como propio por importantes sectores sociales, y para esto el propio proyecto político, económico y social, debía demostrar efectos en condiciones de ser positivamente valorados.

Tales dimensiones, cotidianidad y proyecto político, pueden observarse en numerosas manifestaciones. Lo cotidiano, no obstante, resulta siempre un recurso efímero, difícilmente observable desde una perspectiva histórica, estrechamente vinculado con la "sensibilidad" que José Pedro Barrán (1990, p. 11) analizó como "una historia de las emociones; de la rotundidad o la brevedad culposa de la risa y el goce; de la pasión que lo invade todo, hasta la vida pública [...]”.

\section{Cotidianidad y proyecto}

La extensa bibliografía sobre las dictaduras compone el cuadro de regímenes que corresponden a un período espeluznante en la historia reciente de las sociedades. Sin embargo, para Christian Ferrer,

Hay una zona poco transitada de esa época que debería ser revisitada: concierne a la positividad de la vida cotidiana, y no solamente a su represión. Esa positividad podría significar que un sustrato comunitario inconfesable sostuvo todo el andamiaje político, económico y cotidiano de aquella época y que tal sustrato no es reducible únicamente al núcleo de estatal-represivo de la época (FERRER, 2007, p. 381).

El punto de vista planteado es clave para el enfoque propuesto. $\mathrm{Si}$ "constituyen la cotidianidad la familia en que nacimos, la que construimos, la revista que leemos, la televisión, el cine, el teatro [...]” (PAMPLIEGA DE QUIROGA, 2007, p. 13), detenerse en la observación de la cotidianidad, esto es, de la normalidad, en un período

\section{CANPHLAC}

Revista Eletrônica da ANPHLAC, ISSN 1679-1061, №. 18, p. 162-188, jan./jul. 2015. http://revista.anphlac.org.br/ 
histórico caracterizado por la alteración y la excepción jurídica, obliga a una perspectiva analítica que sin soslayar los signos del terror, se desplace hacia los signos de la relación entre sociedad y gobierno. Una relación que en las dictaduras está marcada por las acciones represivas, y su contracara, la resistencia, pero también por las mutuas acciones afirmativas.

Un examen de la cotidianidad en dictadura se encuentra invariablemente con "[...] un territorio poco conocido, escasamente explorado, quizás por escarpado y problemático" (FERRER, 2007, p. 379). Por ello la bibliografía que más se ha ocupado de este aspecto es la testimonial, y solo en ocasiones, para hacer referencia al estado de soledad que vivieron las víctimas de la represión. ${ }^{3}$ En rigor, la bibliografía que se acerca a este punto de vista lo hace manteniéndose siempre en lo represivo, con énfasis en la resistencia, sin apartarse de la perspectiva que presenta a las dictaduras como regímenes extraordinarios, $\mathrm{y}$, sobre todo, discontinuos.

En cambio, el foco en la cotidianidad en dictadura es el estudio de la normalidad en un contexto de acontecimientos explícitamente determinados como excepcionales y pasajeros pero pretendidamente legítimos y positivamente evaluados: por un lado una legitimidad que -rota la legitimidad de la legalidad democrática- descansa en los fines de la dictadura, y por otro una aceptación cotidiana que involucró a no pocos sectores de la sociedad, que depositaron esa cuota de confianza permanentemente reclamada por la propaganda oficial.

Este mecanismo de legitimación a posteriori de un "proceso" en curso que desembocará en una reorganización política y social, coincide con la verificación de Norberto Bobbio cuando observa que "si las dictaduras existen, sirven, a decir de los autócratas, sólo para restaurar en el más breve lapso posible la «verdadera» democracia, que naturalmente deberá ser mejor que la suprimida por la violencia" (BOBBIO, 2009, p. 405). El conflicto entre transitoriedad y permanencia se resuelve así perfectamente en

\footnotetext{
${ }^{3}$ Referencias a la escasa solidaridad, la indiferencia o directamente el rechazo en su entorno social e incluso familiar que recibieron las víctimas directas de la dictadura, pueden encontrarse, con frecuencia de forma marginal, en varias publicaciones testimoniales. Dos textos altamente representativos de esta mirada se encuentran en los artículos de Marisa Ruiz (2006) que indaga en el relato de familiares de presos políticos durante la dictadura, y de Virginia Martínez (2006), que realiza un importante ejercicio de memoria sobre su propia experiencia.
}

\section{GANPHLAC}

Revista Eletrônica da ANPHLAC, ISSN 1679-1061, №. 18, p. 162-188, jan./jul. 2015. http://revista.anphlac.org.br/ 
la legitimidad de los fines, ya que se trata de regímenes que "[...] practican la dictadura y la represión en el presente al par que prometen la democracia y la libertad para el futuro" (O’DONNELL; SCHMITTER, 2009, p. 41).

La transitoriedad - la dictadura uruguaya se concibió a sí misma como un "proceso"- que sustenta la "excepcionalidad" del período y se justifica en la promesa del futuro, determina en consecuencia una cotidianidad compleja no exenta de contradicciones. Si la cotidianidad se define como "[...] el modo de organización material y social de la experiencia humana, en un contexto histórico - social determinado" (PAMPLIEGA DE QUIROGA, 2007, p. 12), especialmente en el caso de la vida cotidiana en dictadura es preciso contraponer la "experiencia humana" al "contexto histórico - social” cuya especificidad está precisamente en la promesa que se relaciona con el éxito del "proceso", esto es, con el cumplimiento de los objetivos legitimadores y que justifican la alteración de los procedimientos.

La institucionalización de nuevos procedimientos reconciliados con los fines manifiestos, se produjo con el intento de reforma constitucional previsto desde el inicio del período dictatorial. El 30 de noviembre de 1980 el régimen sometió a consulta popular un proyecto de reforma constitucional que articulaba con absoluta claridad los fines de la dictadura. Naturalmente, su aprobación habría sido la confirmación de un cambio en la cultura política de los uruguayos, que hasta entonces se vinculaba con toda la serie de comportamientos, de líderes y ciudadanos, resultantes de la acción de los dos partidos políticos que conformaban un persistente bipartidismo, y cuyos protagonistas, los partidos Colorado y Nacional -organizaciones largamente fraccionalizadas-, se enfrentaron por décadas en complejas competencias inter e intrapartidarias en un mismo acto electoral.

Cotidianidad y proyecto institucional están, en esta interpretación, fuertemente implicados. La aspiración reformista del régimen se asentaba en la vinculación de las dos dimensiones, en la medida que la articulación institucional debía ser el resultado de una transformación subjetiva del ciudadano que permitiera el abandono de una cultura política arraigada, históricamente construida a lo largo del siglo XX, con dos partidos políticos enfrentados y que dirimían sus diferencias en el plano electoral. La

\section{BANPHLAC}

Revista Eletrônica da ANPHLAC, ISSN 1679-1061, №. 18, p. 162-188, jan./jul. 2015. http://revista.anphlac.org.br/ 
cotidianidad en dictadura conlleva, entonces, la práctica de sedimentación de una cultura política radicalmente distinta a la construida en la primera mitad del siglo, a su vez legitimadora, mediante el procedimiento del voto, de la solución institucional propuesta en el proyecto de reforma constitucional de 1980.

\section{El proyecto político}

El nuevo formato institucional emergería de la incorporación al texto constitucional de una serie de mecanismos jurídicos que garantizarían la acción de un gobierno unificado, incompatibles con las divisiones propias del sistema político tradicional. ${ }^{4}$ Sin entrar en las determinaciones históricas de la conformación del sistema de partidos que predominó en el Uruguay del siglo XX, los partidos tradicionales, o las fracciones de cada uno de ellos, cohabitaron en el gobierno y en la oposición. La construcción del Estado moderno y la coparticipación en el mismo a lo largo del siglo $\mathrm{XX}$ generó las condiciones para la fortaleza de un consenso en torno a los valores democráticos expresados, inicialmente, en la pureza del sufragio como resultado de cada contienda electoral (SOLARI, 1967, p. 141). Este paso marcó la modernización de los partidos y la conformación de una cultura política, que se presenta hasta hoy, siguiendo a Constanza Moreira (2000, p. 104), “[...] consistente en todos sus indicadores: preferencias por la democracia, actitud positiva hacia las instituciones políticas y confianza en las reglas del juego democráticas". En suma, una cultura política entregada a la competencia electoral y a las reglas del sistema mayoritario como mecanismo para el acceso al poder y la legitimación de las decisiones vinculantes, que

\footnotetext{
${ }^{4}$ El Partido Colorado y el Partido Nacional (o Partido Blanco), los llamados "partidos tradicionales", dominaron el sistema político uruguayo desde el S XIX, hasta la ruptura del bipartidismo en 1973 con el surgimiento del Frente Amplio, una coalición de partidos y movimientos de izquierda y centro izquierda. Una característica permanente de ambos partidos, y también del Frente Amplio, sigue siendo la alta fraccionalización, o sea, la presencia de múltiples fracciones al interior de los partidos que compiten internamente. A principios de la década del 70, las divisiones internas de los partidos tradicionales fueron lo suficientemente profundas como para dificultar la reunión de mayorías parlamentarias sólidas para gobernar, situación a la que de forma permanente el régimen cívico - militar hizo referencia.
}

\section{CANPHLAC}

Revista Eletrônica da ANPHLAC, ISSN 1679-1061, №. 18, p. 162-188, jan./jul. 2015. http://revista.anphlac.org.br/ 
tempranamente sustituyó el conflicto armado por el conflicto político y electoral, agudizado a principios de los años setenta.

Contrariamente a esta determinación histórica, el presidente uruguayo de facto Juan María Bordaberry ${ }^{5}$ señalaba, en 1975, que el objetivo del régimen cívico - militar consistía en la "[...] creación de una nueva institucionalidad, que recogiendo la triste experiencia padecida, consolide una sociedad uruguaya, una sociedad oriental, próspera, feliz y en paz". ${ }^{6} \mathrm{La}$ "triste experiencia" refería siempre al rol desempeñado por los partidos políticos tradicionales en los años previos a la disolución del Parlamento, contradictoria con la unidad nacional, la "sociedad oriental"7 que el proyecto perseguía. Un año y medio después, su sustituto, Aparicio Méndez, ${ }^{8}$ pese a que los partidos tradicionales se encontraban suspendidos, hizo referencia en un discurso público a la forma de participación política como unión de los partidos, en los siguientes términos: "En el nuevo Uruguay, los Partidos Políticos deben actuar así, unidos para el bien de la Nación [...]. Y no sólo a través de campañas electorales estentóreas, los pueblos se pueden encontrar con los gobiernos". ${ }^{9}$ La idea de unión, la existencia de una comunidad nacional como valor superior, que imponía un límite fuerte al conflicto entre las preferencias partidarias, fue una fórmula permanentemente sostenida por la dictadura y la piedra angular de la cultura política que se esperaba conformar.

\footnotetext{
${ }^{5}$ Juan María Bordaberry fue elegido presidente por el Partido Colorado en elecciones constitucionales en 1971. Menos de dos años después, apoyado en los militares, disolvió el Parlamento por decreto (Decreto 464/973) y lo sustituyó por un Consejo de Estado designado por el Poder Ejecutivo, hecho que dio inicio a doce años de dictadura en Uruguay. Al Consejo de Estado, el propio decreto le asignaba también la redacción de un nuevo texto constitucional.

${ }^{6}$ Citado en el editorial "Hacia una nueva institucionalidad uruguaya" del diario El País de Montevideo, 04 de enero de 1975 , p. 5.

${ }^{7}$ Por ejemplo, 1975 fue declarado "Año de la Orientalidad" en Uruguay. Esta idea de "orientalidad" se significaba como la condición común a todos los ciudadanos que eliminaba las distancias representadas por elementos como la clase, el partido político, la ideología. El trabajo de Cose y Markarian (1996) repasa, desde una perspectiva histórica, la intensa propaganda realizada ese año.

${ }^{8}$ Aparicio Méndez, abogado y docente universitario, fue miembro del Consejo de Estado y sustituyó a Bordaberry luego de su alejamiento por discrepancias en el interior del gobierno cívico - militar en torno al futuro de los partidos políticos. Nombrado por un organismo creado en dictadura, el Consejo de la Nación, asumió la presidencia el 1 de setiembre de 1976.

${ }^{9}$ Noticia "Méndez destacó función de partidos tradicionales". Diario El Día de Montevideo, 26 de junio de 1977, p. 1. El discurso de Méndez hizo referencia a la participación de líderes políticos pertenecientes a los partidos Colorado y Nacional en la ejecución de obras públicas en el departamento de Cerro Largo.
}

\section{GANPHLAC}

Revista Eletrônica da ANPHLAC, ISSN 1679-1061, №. 18, p. 162-188, jan./jul. 2015. http://revista.anphlac.org.br/ 
Mientras el concepto se instalaba en los discursos y en la propaganda, el proyecto de reforma constitucional propuesto por el régimen, ${ }^{10}$ era absolutamente funcional en el sentido del marco institucional que promovía. "La sociedad tenía que ser integrada y «ensamblada» con un Estado que sería transformado en un «eficiente» conjunto de instituciones" (O’DONNELL, 2009, p. 88), y el modelo planteado ordenaba una serie de cambios institucionales que abarcaban tres aspectos bien definidos: primero, nuevas reglas electorales que obligaban a los partidos a modificar su estructura interna, junto con la prohibición de permanencia a los partidos de izquierda; segundo, cambios en la relación entre los poderes del Estado que favorecían al Poder Ejecutivo en detrimento del Legislativo; tercero, la incorporación de mecanismos de control sobre todo el sistema político, materia reservada principalmente a papel que las Fuerzas Armadas desempeñarían en el nuevo régimen. El proyecto era preciso en su cometido de constreñir a los partidos para favorecer la transformación de todo el sistema, afectando tanto a las unidades como a los vínculos institucionales entre la organización partidaria, los líderes y los ciudadanos.

Los ejes de la institucionalidad propuesta -unidad partidaria, fortalecimiento del Ejecutivo como expresión de la unidad de la nación, y mecanismos de control de estos resultados- significaban un cambio de magnitud que solo sería posible si la misma cultura política terminaba por transformarse, si al menos una porción importante de la ciudadanía aceptaba como adecuada la crítica sistemática de la cultura política y la institucionalidad anterior a 1973. La unidad partidaria se alcanzaría con nuevas reglas electorales que eliminaban la acumulación de votos de las fracciones de los partidos, mecanismo que permitía la múltiple candidatura a todos los cargos electivos. ${ }^{11}$ En una esfera mayor, la unidad nacional se expresaría en la mayoría parlamentaria para el partido ganador, independientemente de su caudal electoral, y la mengua de los

${ }^{10}$ Las referencias al contenido del proyecto de reforma constitucional son tomadas de las pocas publicaciones académicas que se detienen en su análisis descriptivo: CORBO, 2006; RICO y otros, 2008.

${ }^{11}$ Se trataba del llamado "doble voto simultáneo", un mecanismo a través del cual los partidos políticos ofrecían al electorado múltiples candidaturas a todos los cargos electivos, incluso a la presidencia de la República. Todos los candidatos de un mismo partido sumaban votos en cada elección, de modo tal que resultaba elegido presidente el candidato más votado del partido más votado. Este procedimiento resultaba del reconocimiento de la fortaleza de las colectividades políticas más allá de las divisiones internas que históricamente las conformaron.

\section{CANPHLAC}

Revista Eletrônica da ANPHLAC, ISSN 1679-1061, №. 18, p. 162-188, jan./jul. 2015. http://revista.anphlac.org.br/ 
controles parlamentarios a la gestión del Poder Ejecutivo. ${ }^{12}$ En tercer lugar, se creaban una serie de organismos de contralor de la estabilidad del sistema, encargados de custodiar los dos niveles de unidad (nacional y partidario, o sea, político y social), que serían, a su vez, instituciones reservadas a la continuidad de la intervención militar en la política. ${ }^{13}$ Inmerso en este nuevo contexto histórico, la exclusión de la izquierda fue contemplada explícitamente en el texto de la reforma, a través de la prohibición de funcionamiento de partidos cuya conformación o contenidos ideológicos mantuvieran relación con organizaciones ilegalizadas por el régimen.

\section{La propaganda cotidiana}

Para un estudio de la cotidianidad en su relación con un proyecto político de innegables pretensiones hegemónicas, el énfasis en lo comunicacional presenta una singular ventaja. Tanto el ámbito de la prensa para indagar en la calidad, tópicos y frecuencias del debate público en la época, como el de la propaganda política que revela los objetivos, aspiraciones y preferencias de grupos y gobiernos, el estudio de los medios, discursos y representaciones, proporciona unidades de análisis accesibles, que de alguna manera formaron parte la cotidianidad de una sociedad en un momento dado.

\footnotetext{
${ }^{12}$ El proyecto de reforma fortalecía significativamente el poder del Ejecutivo mediante cambios en la relación de los poderes del Estado, especialmente con el Poder Legislativo. El partido ganador obtendría la mayoría absoluta de representantes en el Parlamento independientemente del número de votos. O sea, se eliminaba la representación proporcional y se garantizaba al partido en el gobierno la mayoría absoluta en ambas Cámaras. Los partidos menores verían reducida su representatividad también por la disminución en el número de legisladores. La Cámara de Senadores pasaba de treinta a veinte senadores, y la Cámara de Diputados se reducía de noventa y nueve a setenta y cinco diputados. El predominio del Poder Ejecutivo se reforzaba, además, con otras disposiciones que obstaculizaban los controles, incrementándose las mayorías necesarias para el llamado a Sala a ministros y para la remisión de pedidos de informes. Significativamente, la sección VII de la Constitución, cuyo título original es "De la proposición, discusión, sanción y promulgación de las leyes", perdía la palabra "discusión" en el texto proyectado.

${ }^{13}$ El proyecto de reforma incorporaba a la Constitución un organismo creado poco antes del golpe de junio de 1973, el Consejo de Seguridad Nacional (COSENA), que pasaría a desempeñarse como organismo de control de conflictos sociales. También creaba el Tribunal de Control Político, un innovador instrumento de contralor político que tendría el cometido, impreciso pero por eso mismo potencialmente efectivo, de "[...] sancionar a las autoridades nacionales, departamentales o partidarias por la comisión de actos que afecten gravemente el ejercicio de la función o la dignidad de su desempeño y siempre que con ello se incurriere en responsabilidad política" (art. 164 del texto proyectado).
}

\section{GANPHLAC}

Revista Eletrônica da ANPHLAC, ISSN 1679-1061, №. 18, p. 162-188, jan./jul. 2015. http://revista.anphlac.org.br/ 
La articulación de los objetivos de la dictadura en un texto constitucional, fue precedida por una larga y por momentos intensa propaganda gubernamental. Y la idea de un "Nuevo Uruguay" en marcha desde 1973 -síntesis de la transformación refundacional que se proponía la dictadura- pero que cristalizaría con la aprobación plebiscitaria del texto constitucional, se reiteró indefinidamente en los discursos públicos, en las noticias de prensa, en la propaganda oficial. El ideal de unión por encima de las partes se concebía como el componente inevitable del "Nuevo Uruguay", al mismo tiempo un proyecto futuro y una realidad cotidianamente evidente que emergía como resultado del proceso iniciado en 1973.

Las reglas y técnicas de la propaganda establecidas por Jean-Marie Domenach (2005, p. 47-81) se ajustan al análisis de las formas que adoptó el gobierno dictatorial para dirigirse directamente a la ciudadanía por este medio. "La persistencia del tema, junto con la variedad de su presentación, es la cualidad rectora de toda campaña de propaganda" (DOMENACH, 2005, p. 60), y en el caso uruguayo el tema no se apartó, desde 1973 hasta 1980, año de la convocatoria a la consulta sobre la reforma, de la idea de unión por sobre los intereses particulares representados por el partido, el sindicato, la organización sectorial. Una unión que exigía la renuncia definitiva a toda otra identidad. El propio decreto de disolución del Parlamento disponía la prohibición de vincular sus disposiciones con propósitos dictatoriales, ${ }^{14}$ cerrando así tempranamente la construcción de cualquier contrapropaganda que disputara el espacio público.

Los primeros avisos oficiales aparecieron en la prensa apenas inaugurada la dictadura, en julio de 1973; a partir de 1974 comenzaron a publicarse series de avisos estatales dirigidos a públicos diversos que culminaron en la campaña publicitaria favorable al voto por SI en el la consulta ciudadana para reformar la Constitución, cuando la propaganda insistía en la adhesión al régimen pero ya mediante el recurso del voto afirmativo al proyecto de reforma, luego de años de acumulación de una intensa campaña oficial.

\footnotetext{
${ }^{14} \mathrm{El}$ artículo $3^{\circ}$ del decreto 464/973 establecía: "Prohíbese la divulgación por la prensa oral, escrita o televisada de todo tipo de información, comentario o grabación que, directa o indirectamente, mencione o se refiera a lo dispuesto por el presente decreto atribuyendo propósitos dictatoriales al Poder Ejecutivo, o pueda perturbar la tranquilidad y el orden públicos".
}

\section{GANPHLAC}

Revista Eletrônica da ANPHLAC, ISSN 1679-1061, №. 18, p. 162-188, jan./jul. 2015. http://revista.anphlac.org.br/ 
La primera campaña utilizó el slogan “póngale el hombro al Uruguay”. En julio de 1973, todavía bajo los efectos de la huelga general de la Convención Nacional de Trabajadores (CNT), ${ }^{15}$ uno de los primeros avisos oficiales convocaba de la siguiente manera a los trabajadores: "Trabajador: es necesario que los sindicatos tengan dirigentes orientales. ¡Pero de corazón! Con un sindicalismo libre y fuerte $-\mathrm{y}$ con dirigentes orientales de verdad- el movimiento obrero será mucho más fuerte [...]” (fig.1). ${ }^{16}$

\section{Figura 1}

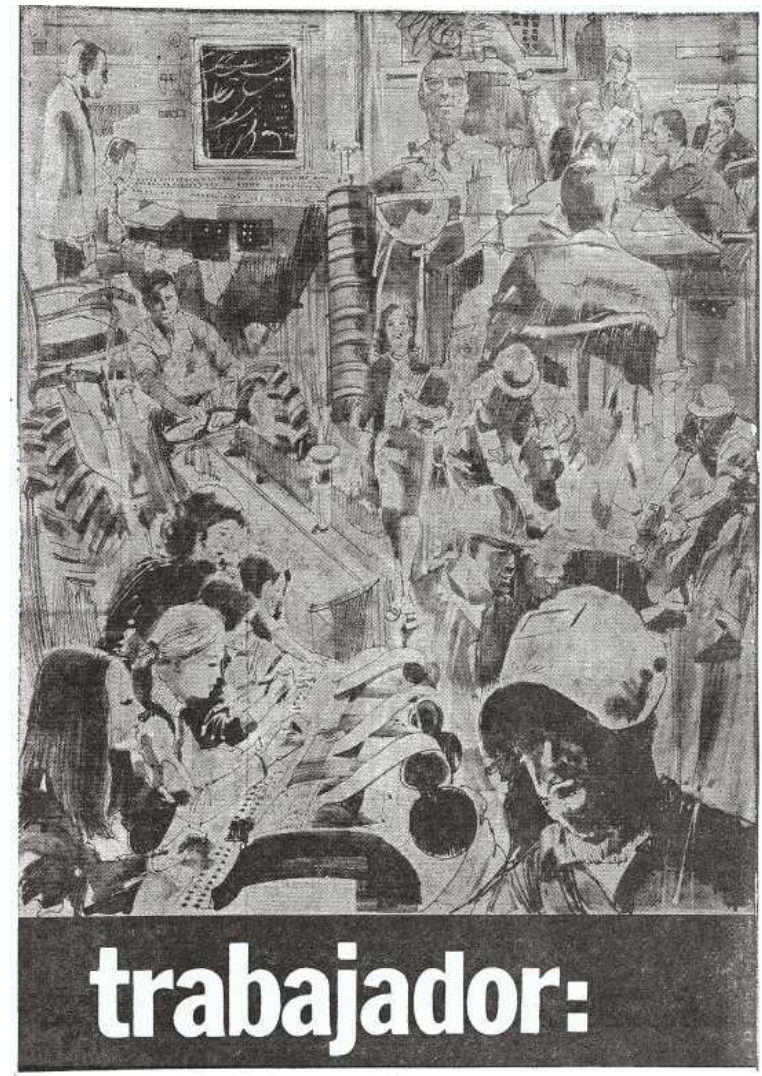

Es necesario que los sindicatos tengan dirigentes orientales. ¡Pero de

Con un sindicalismo libre y fuerte $-\mathrm{y}$ con dirigentes orientales de verdadMás fuerte para defender los derechos del trabajador y libre -por finDecidase $y$.

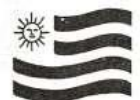

jPONGALE EL hOMBRO AL URUGUAY'

\footnotetext{
${ }^{15}$ La central de trabajadores CNT, que agrupaba desde 1964 a todos los sindicatos de trabajadores, convocó a una huelga general en rechazo a golpe que se extendió durante quince días.

${ }^{16}$ Publicado en El País de Montevideo, 15 de julio de 1973, p. 13.
}

\section{GANPHLAC}

Revista Eletrônica da ANPHLAC, ISSN 1679-1061, №. 18, p. 162-188, jan./jul. 2015. http://revista.anphlac.org.br/ 
Las referencias al sindicalismo, aun remitiéndolo a una condición no "oriental", esto es, ajena a lo nacional, fueron escasas y desaparecieron de las publicaciones en 1975, no así las referencias en general al trabajador. Pero en 1974 todavía era posible encontrar avisos como los de la serie "Yo, oriental", que establecían una sentencia en primera persona atribuida a distintos personajes vinculados con los diversos roles en la sociedad, que en relación al papel de dirigente sindical formulaba: "Voy a preferir el camino del entendimiento fecundo a la opción del enfrentamiento estéril. [...] Voy a combatir por un gremialismo honesto, apolítico y auténticamente oriental" (fig.2). ${ }^{17}$

\section{Figura 2}

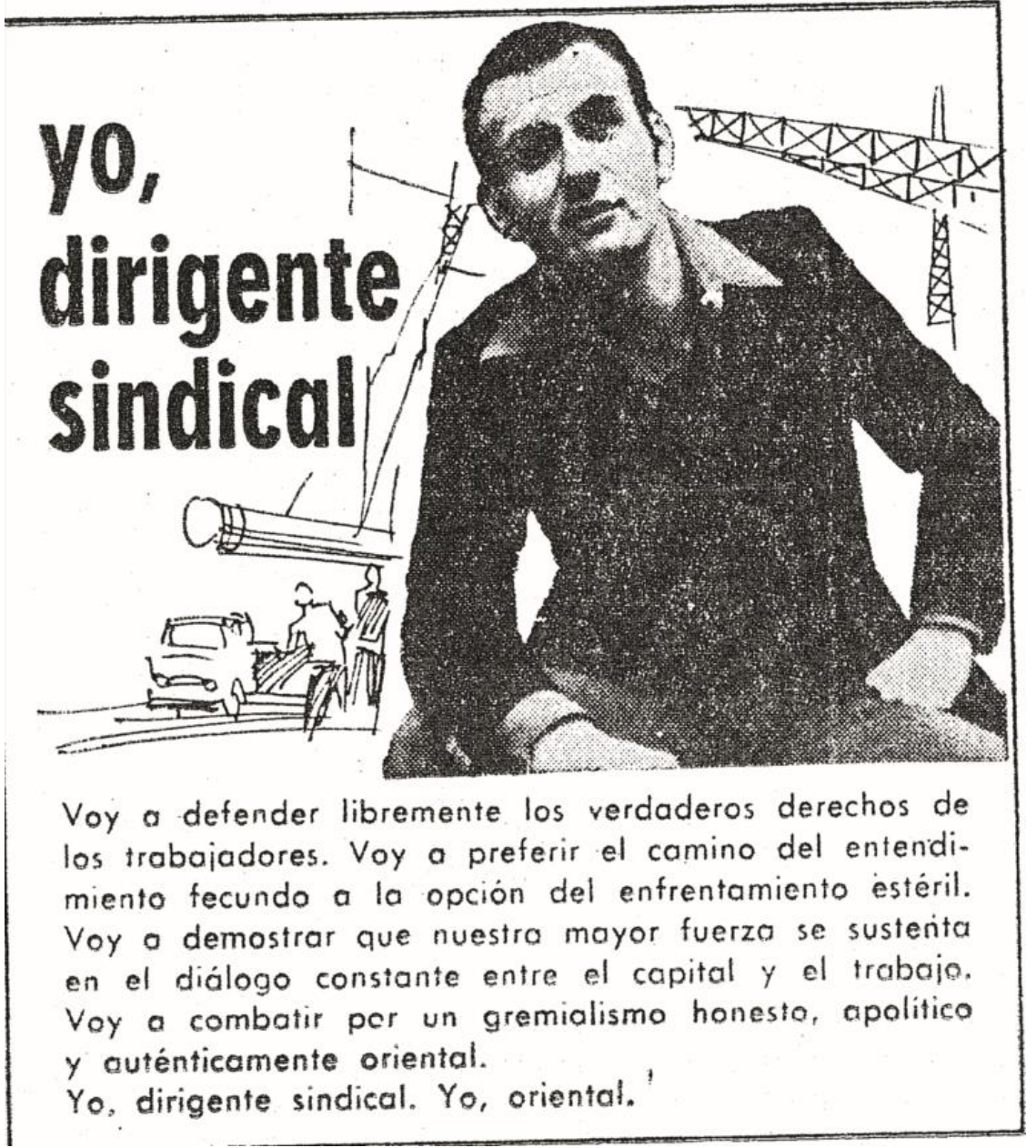

${ }^{17}$ Publicado en El País, 11 de agosto de 1974, p. 11.

\section{GANPHLAC}

Revista Eletrônica da ANPHLAC, ISSN 1679-1061, №. 18, p. 162-188, jan./jul. 2015. http://revista.anphlac.org.br/ 
Otro aviso de esta serie hacía referencia al rol del gobernante, como "hombre público" que involucra tanto al político como a quien asumió cargos de gobierno durante el régimen: "He roto con los viejos esquemas. [...] He renunciado a las promesas fáciles. Me he impuesto las obligaciones más severas. Trabajo para todos, menos para mí. Soy un servidor incondicional de mi país" (fig.3). ${ }^{18}$

\section{Figura 3}

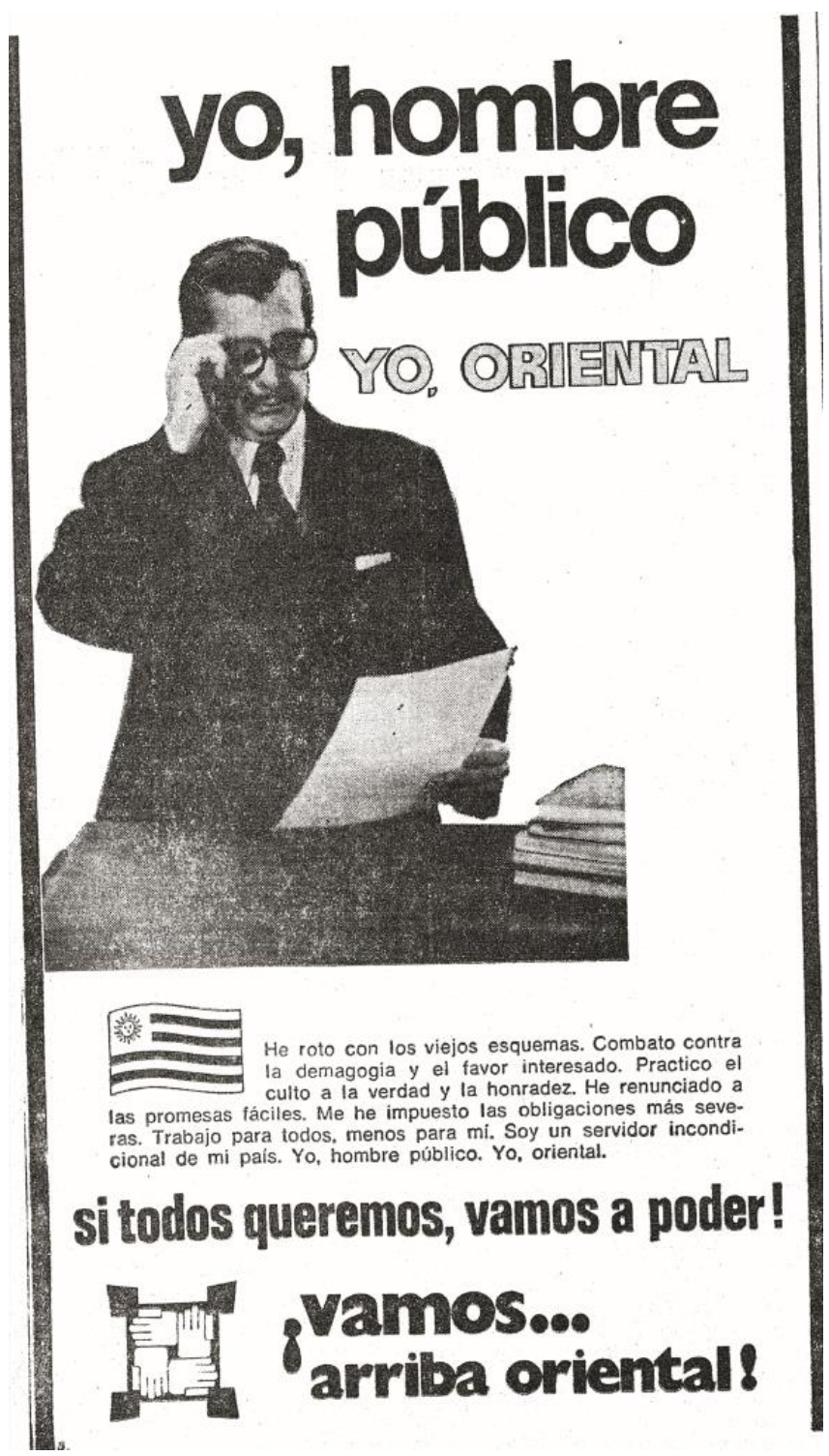

\footnotetext{
${ }^{18}$ Publicado en El País, 03 de setiembre de 1974, p. 10.
}

\section{GANPHLAC}

Revista Eletrônica da ANPHLAC, ISSN 1679-1061, №. 18, p. 162-188, jan./jul. 2015. http://revista.anphlac.org.br/ 
Ese mismo año, iniciada la intervención de la Universidad de la República, se publicaron avisos que hacían referencia a una "reforma" de la institución de enseñanza; una publicación expresaba: "Reformamos la Universidad para que nuestros hijos puedan estudiar en paz. Por un Uruguay para todos los buenos Orientales. JUNTOS LO HACEMOS MEJOR! (fig.4). ${ }^{19}$

\section{Figura 4}

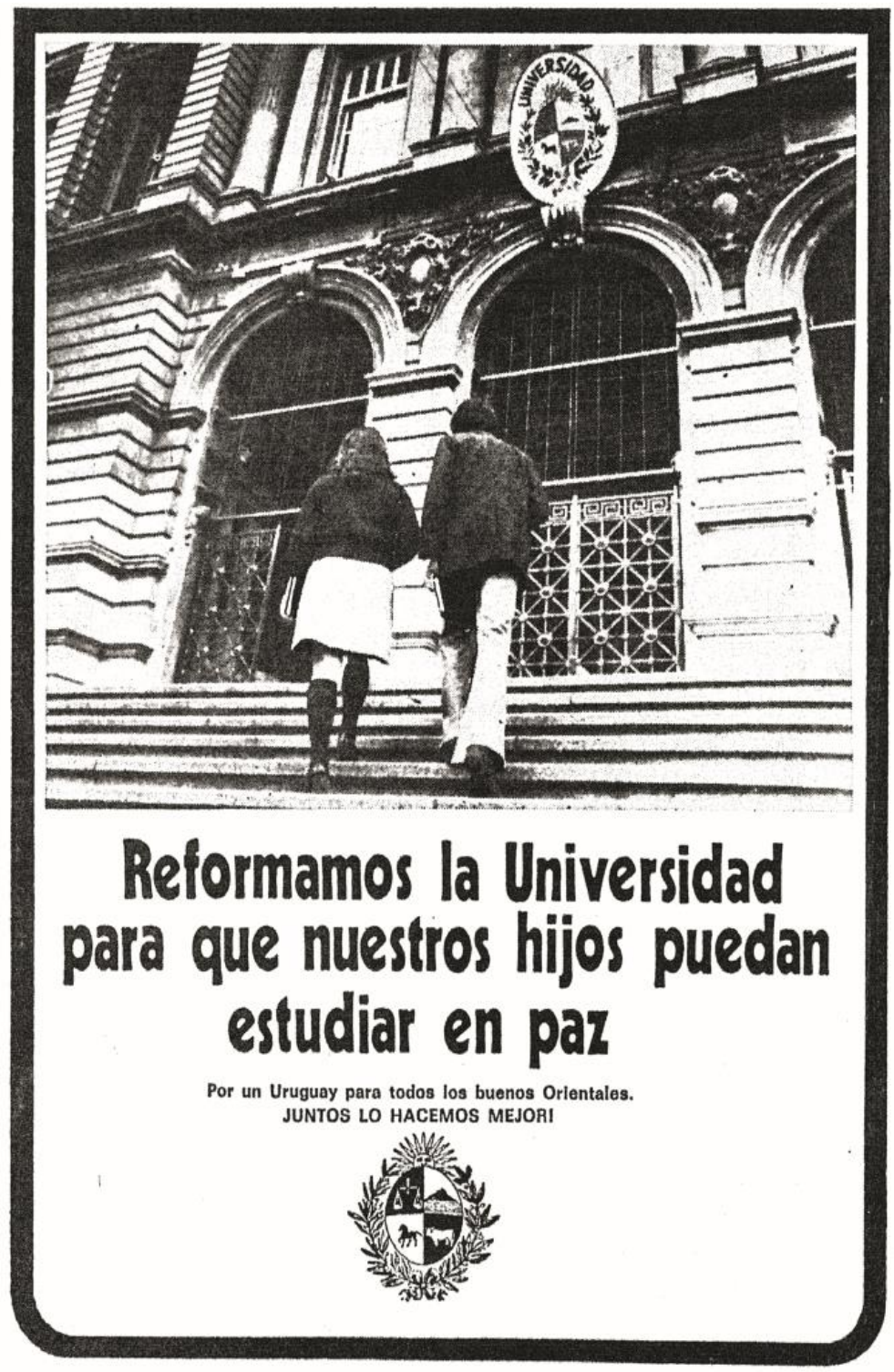

${ }^{19}$ Publicado en El País, 08 de agosto de 1974, p. 4.

\section{CANPHLAC}

Revista Eletrônica da ANPHLAC, ISSN 1679-1061, №. 18, p. 162-188, jan./jul. 2015. http://revista.anphlac.org.br/ 
Con claridad, el país y la Universidad, eran instituciones reservadas a "los buenos Orientales", a éstos se dirigía la necesidad de unión al tiempo que implícitamente se reconocía una necesaria exclusión.

En 1975, el ideal de unión impregnó todas las publicaciones. La serie de avisos "El Uruguay somos todos" fue significativa en este concepto, que presentó como definitivamente alcanzado: “[...] Por fin lo hemos comprendido. Por fin sabemos que somos una gran familia de hermanos. Por fin somos concientes (sic) de todo lo mucho que nos une y de lo poco que nos separa (fig. 5). ${ }^{20}$

\section{Figura 5}

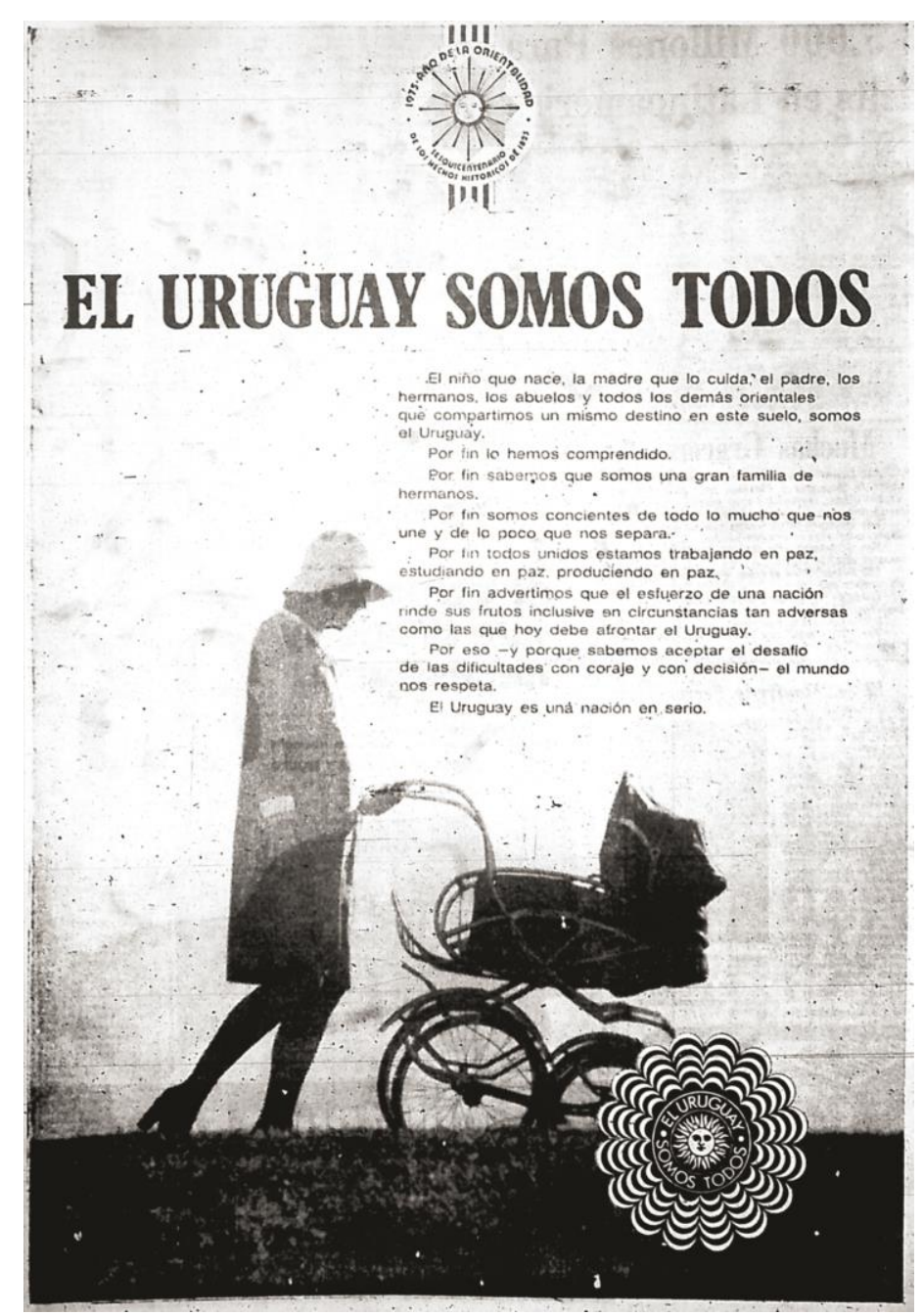

${ }^{20}$ Publicado en El Día de Montevideo, 28 de julio de 1975, p. 6.

\section{GANPHLAC}

Revista Eletrônica da ANPHLAC, ISSN 1679-1061, №. 18, p. 162-188, jan./jul. 2015. http://revista.anphlac.org.br/ 
Otro aviso posterior de la misma serie, reiteraba la misma idea en los siguientes términos: "Todos los niños, todos los padres, todos los hermanos, somos el Uruguay. [...] Si alguna vez lo habíamos olvidado, ahora somos conscientes que una nación es una familia de hermanos" (fig.6). ${ }^{21}$

\section{Figura 6}

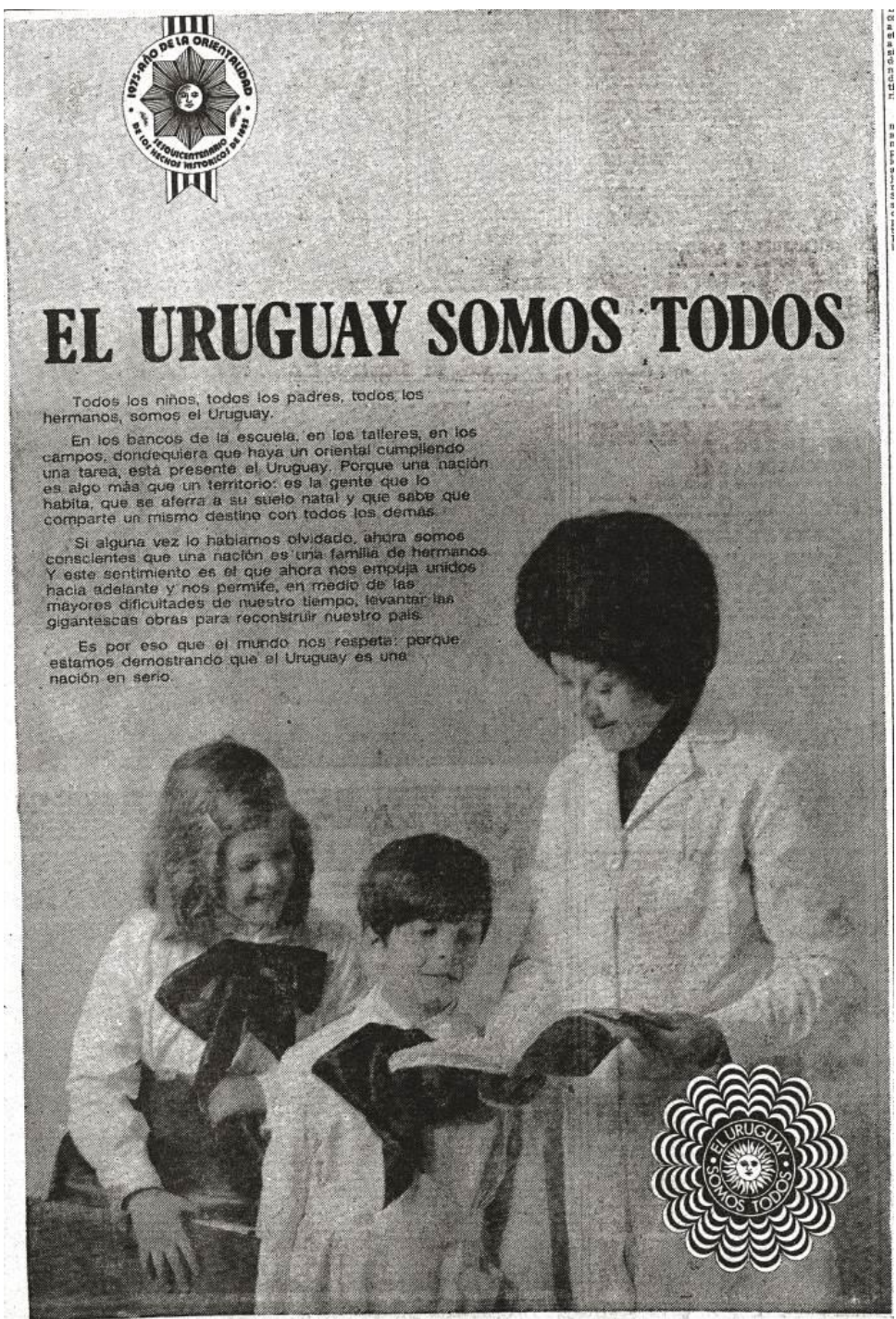

${ }^{21}$ Publicado en El País, 14 de agosto de 1975, p. 10.

\section{GANPHLAC}

Revista Eletrônica da ANPHLAC, ISSN 1679-1061, №. 18, p. 162-188, jan./jul. 2015. http://revista.anphlac.org.br/ 
Ese mismo año otra serie titulada “¡Vamos... arriba oriental!” publicó numerosos avisos que ligaban la idea de unión con el requisito para el desarrollo económico y social. Una de las publicaciones se valió de la metáfora popular del bote sobre el mar que requiere que todos remen a la par. La ilustración consistía en un bote con varias personas a bordo aproximándose a la costa; uno de los individuos se destaca con los brazos cruzados cuando los demás reman con esfuerzo. El título del aviso es veladamente amenazante: "un momento, amigo: o remamos todos, o...", antes del texto que refuerza la significación de la imagen: "Créalo. En este bote, nadie puede esperar que los demás hagan su parte. Si queremos llegar a tierra firme, tenemos que remar todos. La empresa del Desarrollo Nacional no admite deserciones ni reticencias" (fig.7). ${ }^{22}$

\section{Figura 7}

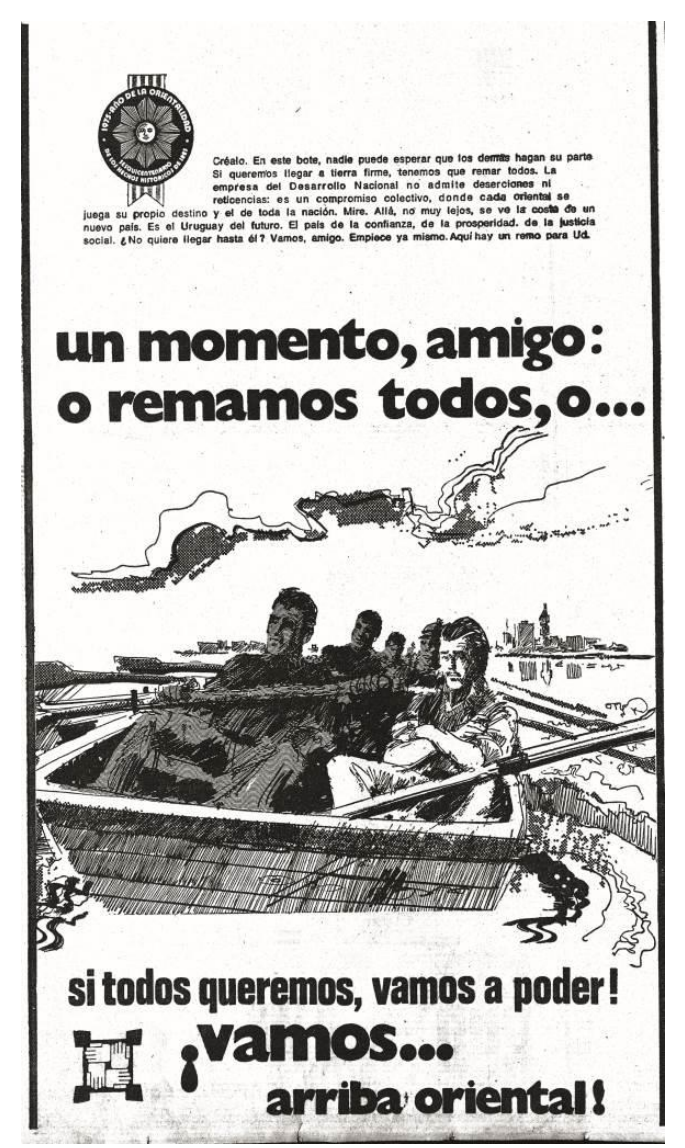

${ }^{22}$ Publicado en El País, 08 de junio de 1975, p. 6.

\section{GANPHLAC}

Revista Eletrônica da ANPHLAC, ISSN 1679-1061, №. 18, p. 162-188, jan./jul. 2015. http://revista.anphlac.org.br/ 
Los jóvenes fueron un público al cual la propaganda se dirigió pero con frecuencia para destacar su avenencia con el mundo adulto. Un aviso publicado en 1976 se dirigía a ese sector de la sociedad, con el título "Dime que sonríes..." y la imagen de dos jóvenes con uniforme: "Los jóvenes Orientales estudian... juegan, trabajan... o practican deportes libre y sanamente. Se unen junto a sus mayores y luchan en el Nuevo Uruguay en busca de su destino" (fig.8). ${ }^{23}$

\section{Figura 8}

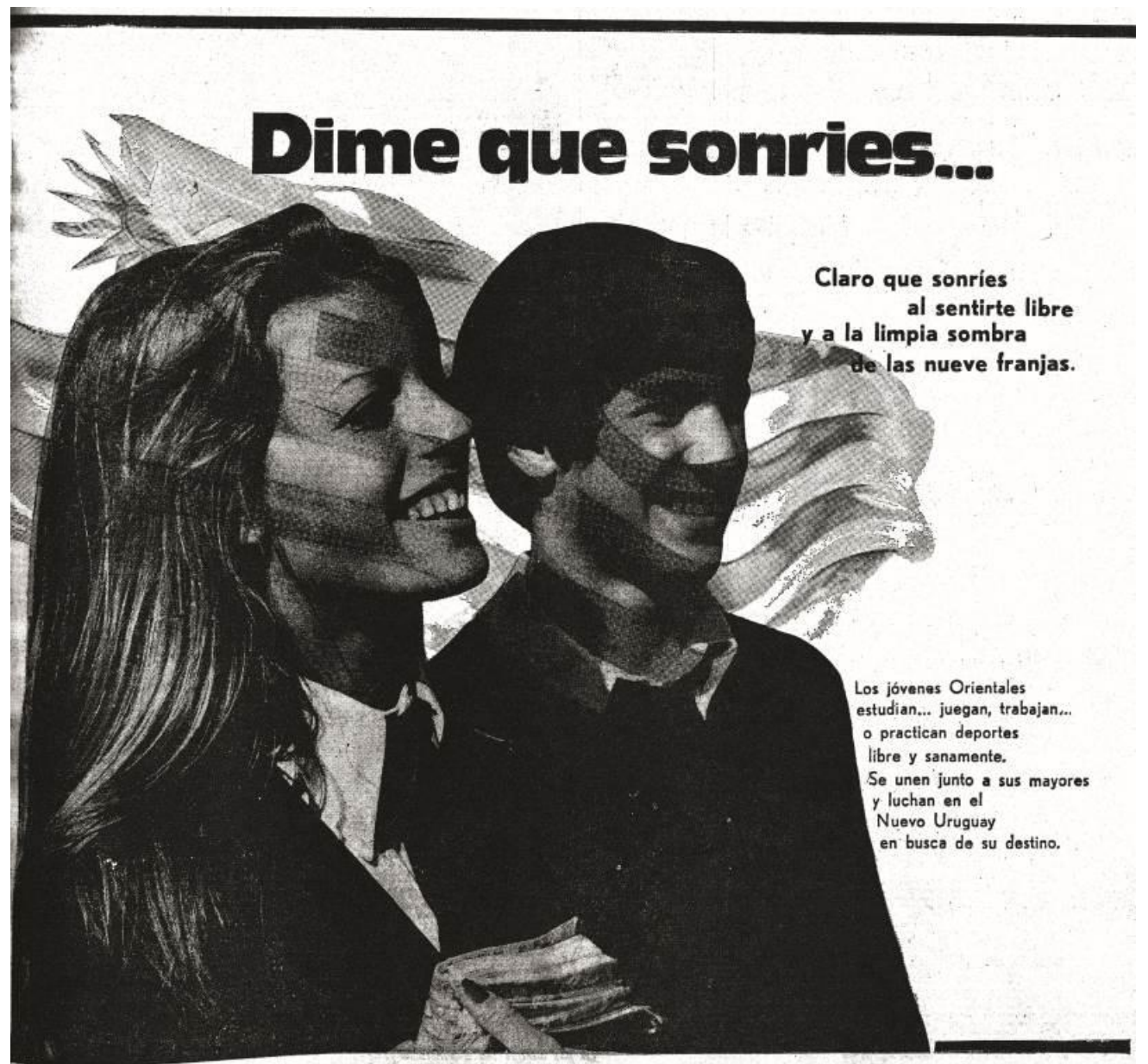

${ }^{23}$ Publicado en La Mañana, 18 de abril de 1976, p. 3.

\section{GANPHLAC}

Revista Eletrônica da ANPHLAC, ISSN 1679-1061, №. 18, p. 162-188, jan./jul. 2015. http://revista.anphlac.org.br/ 
Sobre la base de toda la propaganda desplegada desde 1973, la campaña estatal en las semanas previas a la consulta de 1980 fue particularmente intensa. La expresión pública por la opción del NO a la reforma fue permitida, si bien las condiciones de la época, en especial la censura a la prensa que pesaba sobre las publicaciones desde 1967, limitaba la difusión de un discurso radical de oposición al régimen. Esto comportó que la campaña oficial por el SI se tornara omnipresente y que el eslogan "Dígale SI al Uruguay" se reprodujera en infinidad de formatos.

Las imágenes a las que recurrió la campaña de 1980 difieren de las utilizadas en los años previos. Con el uso exclusivo de la fotografía pasa a simbolizar la paz, el desarrollo y el "estilo de vida" propio de los "orientales", ya no solamente la propaganda es cotidiana, aquello a lo que permanecían expuestos los uruguayos con aguda frecuencia, sino que la misma propaganda acude a imágenes de la cotidianidad: el mate, abuelos en las plazas, los niños y el fútbol, las obras de infraestructura realizadas, el aula finalmente en orden, el bar, los paseos al aire libre. La cotidianidad anterior, asociada a la violencia política, el estancamiento económico, el caos social, ha sido superada y sin embargo la nueva Constitución asegura el éxito del proyecto: "Hace muy pocos años estuvimos a punto de perder nuestro estilo de vida, nuestra libertad, nuestras costumbres. Por eso la nueva Constitución refleja la manera de ser, de vivir y de convivir de los orientales" (fig. 9). ${ }^{24}$

\footnotetext{
${ }^{24}$ Publicado en El País, 22 de octubre de 1980, p. 4.
}

\section{CANPHLAC}

Revista Eletrônica da ANPHLAC, ISSN 1679-1061, №. 18, p. 162-188, jan./jul. 2015. http://revista.anphlac.org.br/ 


\section{Figura 9}

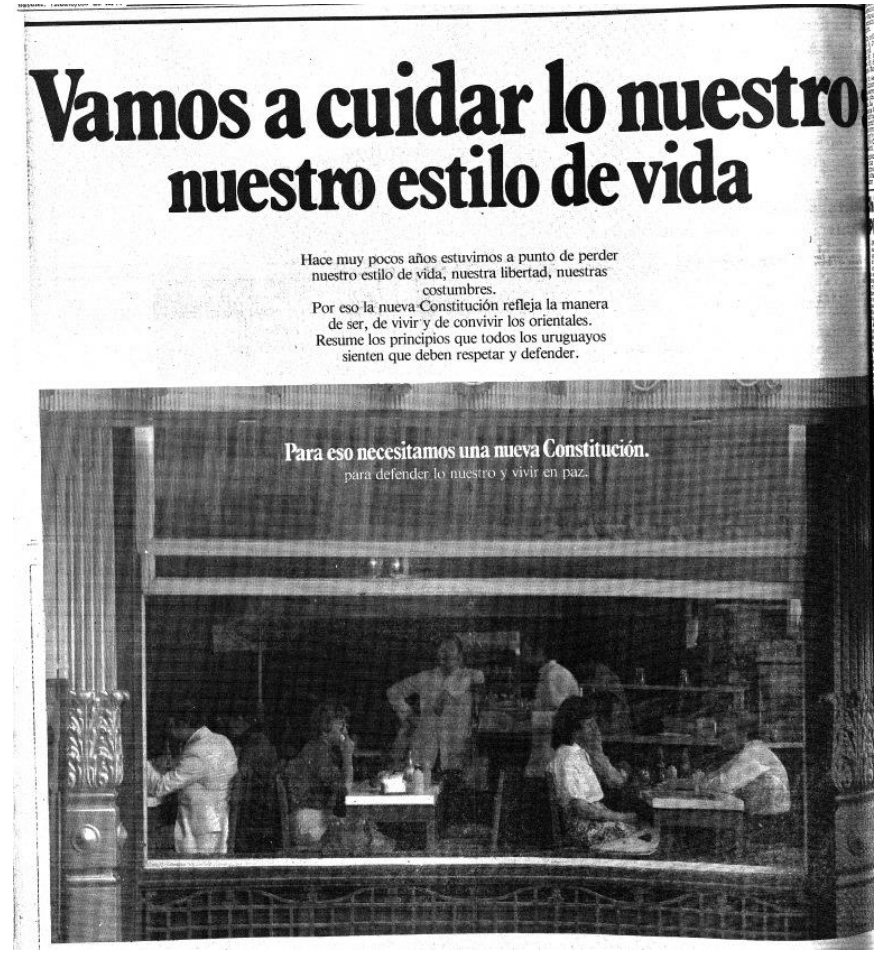

Toda la campaña propagandística de la dictadura culminó en noviembre de 1980 con la confluencia perfecta de las dos dimensiones que hemos manejado. El proyecto político, su discurso legitimador, los fines de progreso, desarrollo, seguridad y paz social que determinaba el fin del conflicto, se reunían en un voto afirmativo al proyecto de la dictadura. Un proyecto constitucional que incluía normas de disciplinamiento sobre los partidos y los ciudadanos, pero que sería el resultado de la aceptación del discurso legitimador de tales fines que el mismo acto electoral confirmaba.

\section{Conclusión}

En el presente trabajo se ha propuesto un estudio de la dictadura que ponga de relevancia dos dimensiones conexas: cotidianidad y proyecto político. Se fundamentó la pertinencia del examen de la propaganda política del régimen como espacio de

\section{GANPHLAC}

Revista Eletrônica da ANPHLAC, ISSN 1679-1061, №. 18, p. 162-188, jan./jul. 2015.

http://revista.anphlac.org.br/ 
verificación de ambas dimensiones, puesto que cada campaña propagandística, cada mensaje, cada discurso puede observarse precisamente como el medio cotidiano a través del cual los ciudadanos se constituían como receptores del contenido de ese proyecto. Las transformaciones institucionales que formulaba, coincidían además con aquello que toda propaganda política busca engendrar, en este caso, una identificación perfecta entre gobierno y ciudadanía, y la consecuente prescindencia de los cuerpos intermedios entre el Estado y la sociedad. Para ello era necesario primero modificar toda la trama de vínculos al interior del sistema político de tal modo que la unidad nacional prevaleciera siempre en las relaciones, y despejar todo aquello que perturbara el orden alcanzado y ostensible en el desarrollo económico y social derivado de la conciliación, el entendimiento y la consecución de un único interés nacional. Junto con la apelación permanente de los mensajes a la adhesión al proyecto, la eliminación violenta de todo foco de resistencia.

Pero las modificaciones en el comportamiento exigidas por las normas dispuestas en la reforma, solo serían posibles con la aprobación y el asentimiento, con la expresión mayoritaria de un SI al proyecto, o sea, a través de la acción afirmativa voluntariamente manifestada. Esta voluntad debía ser el resultado de la expansión de una cultura política que segregara toda idea de diferenciación, todo valor positivo del disenso y la oposición.

A diario los uruguayos estuvieron expuestos durante años a una propaganda en este sentido. Una propaganda que, finalmente, acudía a la cotidianidad para demostrar que el objetivo de la dictadura, el orden, el desarrollo económico, la paz social, habían sido alcanzados y formaban parte de la misma vida cotidiana de los uruguayos que, en tanto adhirieran a estos objetivos y los integraran a su propia subjetividad, estarían en condiciones de permanecer incluidos en la comunidad política.

Esta mirada en la cotidianidad, y su relación con el proyecto político y social del régimen cívico - militar, permite aproximarse a una perspectiva que intenta responder a las causas. No tanto a las circunstancias que hicieron posible, políticamente y socialmente, la emergencia de una dictadura, sino los asientos ideológicos; no tanto las oportunidades como los principios y las aspiraciones más arraigadas.

\section{CANPHLAC}

Revista Eletrônica da ANPHLAC, ISSN 1679-1061, №. 18, p. 162-188, jan./jul. 2015. http://revista.anphlac.org.br/ 
El resultado de la consulta a las urnas, adverso para la dictadura -el NO obtuvo el 55,95 \% y el SI alcanzó el 41,86 \% de los votos-, demostró que el cambio en la subjetividad, si se produjo, no fue lo suficientemente amplio como para favorecer un cambio institucional. La disposición de todos los recursos persuasivos y coercitivos a favor de una idea no parecen determinantes del éxito de una dirección. Sin embargo la perspectiva propuesta no intenta demostrar cómo o bajo qué condiciones se produce o no un cambio en la cultura política, sino exponer la relevancia de dimensiones que permitan acercarnos a una explicación teórica que responda al porqué.

La descripción del período y sobre todo la investigación que busca conocer la verdad sobre los crímenes cometidos durante las dictaduras, es la base de la no repetición. Ella misma demuestra de distintas maneras que otra subjetividad puede permanecer aún en un ambiente hostil que intenta extirparla. Pero una explicación teórica obliga a indagar también en aquello que resulta enteramente propio a las sociedades, si la transitoriedad de las dictaduras no implica ruptura y puede concebirse como la radicalización transitoria de procesos permanentes, y no como la irrupción de elementos externos y ajenos a las sociedades mismas.

\section{GANPHLAC}

Revista Eletrônica da ANPHLAC, ISSN 1679-1061, №. 18, p. 162-188, jan./jul. 2015. http://revista.anphlac.org.br/ 


\section{Bibliografía}

BARRÁN, José Pedro. Historia de la sensibilidad en Uruguay. La cultura "bárbara": (1800-1860). Ediciones de la Banda Oriental: Montevideo, 1990.

BOBBIO, Norberto. Teoría general de la política. Editorial Trotta: Madrid, 2009.

CASULlO, Nicolás. Itinerarios de la Modernidad. Corrientes de pensamiento y tradiciones intelectuales desde la ilustración hasta la posmodernidad. Buenos Aires: Eudeba UBA, 1996.

CORBO, Daniel. El plebiscito constitucional de 1980. La derrota del proyecto militar para legitimar un régimen autoritario. Ediciones Puerta del Sur: Montevideo, 2006.

CRENZEL, Emilio. La historia política del Nunca Más. Siglo XXI: Buenos Aries, 2008.

DOMENACH, Jean-Marie (2005). La propaganda política. Eudeba: Buenos Aires, 2005.

FERRER, Christian. "Un recuerdo de la vida cotidiana durante la dictadura", In: INVERNIZZI, Hernán; GOCIOL, Judith. Un golpe a los libros. Represión a la cultura durante la última dictadura militar. Eudeba: Buenos Aires, 2007, p. 377-381.

GATTI, Gabriel. El detenido-desaparecido. Narrativas posibles para una catástrofe de la identidad. Trilce: Montevideo, 2008.

MARCHESI, Aldo; MARKARIAN, Vania; RICO, Álvaro; YAFFÉ, Jaime. Pensar el pasado reciente: antecedentes y perspectivas. In: El presente de la dictadura. Estudios y reflexiones a 30 años del golpe de Estado en Uruguay. Trilce: Montevideo, 2004, p. 512.

MARKARIAN, Vania; MARCHESI, Aldo. Cinco décadas de estudios sobre la crisis, la democracia y el autoritarismo en Uruguay. Revista Contemporánea, Montevideo, n 3, 2012, p. 213-242.

MARTÍNEZ, Virginia. Una manera de decir aquí estoy, te quiero. Cuadernos de la historia reciente. 1968 Uruguay 1985. Montevideo, n 1, 2006, p. 89-92.

MOREIRA, Constanza. Las paradojales elecciones de fin de siglo uruguayo: comportamiento electoral y cultura política. In: BOTTINELLI, Oscar, y otros. Elecciones 1999/2000. EBO-ICP: Montevideo, 2000, p. 87-109.

O’DONNELL, Guillermo. El estado burocrático autoritario. Buenos Aires: Prometeo, 2009.

\section{GANPHLAC}

Revista Eletrônica da ANPHLAC, ISSN 1679-1061, №. 18, p. 162-188, jan./jul. 2015.

http://revista.anphlac.org.br/ 
PAMPLIEGA DE QUIROGA, Ana. Psicología social y crítica de la vida cotidiana. In: PICHON-RIVIÈRE, Enrique; PAMPLIEGA DE QUIROGA, Ana. Psicología de la vida cotidiana. Nueva Visión: Buenos Aires, 2007.

RICO, Álvaro, y otros. Investigación histórica sobre la dictadura y el terrorismo de Estado en Uruguay (1973-1985), Tomo III. Montevideo: FHCE - Universidad de la República, 2008.

RICO, Álvaro. Cómo nos domina la clase gobernante. Orden político y obediencia social en la democracia posdictadura. Trilce: Montevideo, 2005.

RUIZ, Marisa. El paquete, el ómnibus, la cola y la visita. Cuadernos de la historia reciente. 1968 Uruguay 1985. Montevideo, n 1, 2006, p. 93-110.

SOLARI, Aldo. El desarrollo social del Uruguay en la posguerra. Alfa: Montevideo, 1967.

STAMPA, Inez; SANTANA, Marco Aurelio; RODRIGUES, Vicente, 2014. Direito à memória e arquivos da ditadura: a experiencia do Centro de Referência Memórias Reveladas. In: THIESEN, Icléia (Org.), Documentos sensíveis. Informação, arquivo e verdade na Ditadura de 1964. Rio de Janeiro: 7Letras.

\section{GANPHLAC}

Revista Eletrônica da ANPHLAC, ISSN 1679-1061, №. 18, p. 162-188, jan./jul. 2015.

http://revista.anphlac.org.br/ 